\title{
Structural, thermal, and spectral investigations of the lanthanide(III) biphenyl-4,4'-dicarboxylates
}

\author{
Justyna Sienkiewicz-Gromiuk • Zofia Rzączyńska
}

Received: 25 April 2012/Accepted: 9 July 2012/Published online: 21 August 2012

(C) The Author(s) 2012. This article is published with open access at Springerlink.com

\begin{abstract}
The lanthanide biphenyl-4,4'-dicarboxylates (bpdc) series of the general formulae $\mathrm{Ln}_{2}(\mathrm{bpdc})_{3} \cdot n \mathrm{H}_{2} \mathrm{O}$, where $\mathrm{Ln}=$ lanthanides from $\mathrm{La}(\mathrm{III})$ to $\mathrm{Lu}(\mathrm{III})$; bpdc $=$ $\mathrm{C}_{12} \mathrm{H}_{5}(\mathrm{COO})_{2}^{2-} ; n=4,5$ or 6 have been obtained by the conventional precipitation method. All prepared complexes were characterized by elemental analysis, simultaneous thermal analyses thermogravimetric-differential scanning calorimetry (TG-DSC) and TG-FT-IR, FT-IR, and FTRaman spectroscopy as well as X-ray diffraction patterns measurements. In the whole series of analyzed complexes the bpdc $^{2-}$ ligand is completely deprotonated. In view of that, four carboxylate oxygen atoms are engaged in the coordination of $\operatorname{Ln}(\mathrm{III})$ ions. The synthesized compounds are polycrystalline and insoluble in water. They crystallize in the low symmetry crystal systems, like monoclinic and triclinic. Heating in the air atmosphere resulted in the multi-steps decomposition process, namely endothermic dehydration and strong exothermic decomposition processes. The dehydration process leads to the formation of stable anhydrous $\mathrm{Ln}_{2} \mathrm{bpdc}_{3}$ compounds which subsequently decompose to the corresponding lanthanide oxides.
\end{abstract}

Keywords Biphenyl-4,4'-dicarboxylic acid · Lanthanide complexes · TG-DSC · TG-FT-IR · FT-IR

\section{Introduction}

Synthesis of metal-based coordination polymers with novel structures constitutes an important area of research.

J. Sienkiewicz-Gromiuk · Z. Rzączyńska $(\square)$

Department of General and Coordination Chemistry, Maria

Curie-Skłodowska University, M. C. Skłodowska Sq. 2, 20-031

Lublin, Poland

e-mail: z.rzaczynska@poczta.umcs.lublin.pl
Coordination polymers (PCPs) represent a unique class of crystalline open framework solids with unprecedented structures and diverse chemical composition [1,2]. These kinds of compounds result from molecular reactions between metal ions and bridging multidentate organic ligands, usually performed under hydro(solvo)thermal conditions [3]. The aromatic polycarboxylates are often employed in a design strategy to construct metal-organic frameworks with special topologies due to their rich coordination chemistry and the predictability of the resulting networks [4-6]. In addition, the aromatic polycarboxylates in conjunction with rare earth metals which possess high and variable coordination numbers and flexible coordination geometries, leading to the formation of the exotic molecular architectures.

Biphenyl-4,4'-dicarboxylic acid $\left(\mathrm{H}_{2} \mathrm{bpdc}\right)$ shows several hallmarks: (1) structural characteristics of two carboxyl groups lying at two opposite sites lead to less space hindrance; (2) biphenyl groups may form rigid frameworks and larger cavities; (3) this ligand is highly reactive in aqueous solutions; (4) bpdc ${ }^{2-}$ molecules interact actively with water molecules via hydrogen bonds [7, 8]. Therefore, the biphenyl-4,4'-dicarboxylic rigid, linear organic O-donor ligand is employed as organic linkers to construct metalorganic coordination compounds with a variety of coordination modes (Fig. 1) and different dimensionalities [8-19].

In our recent study on coordination polymers, a series of lanthanide(III) complexes using biphenyl-2,2'-dicarboxylic acid have been synthesized [20]. In this article, as a continuation of our previous work, we introduce the structural, thermal, and spectral investigations of lanthanide(III) coordination compounds based on another isomer of biphenyldicarboxylic ligand, namely biphenyl-4,4'-dicarboxylic acid. The principal aim of this study is the thermal research including the studies over thermal stability, pathway of decomposition process during heating under 

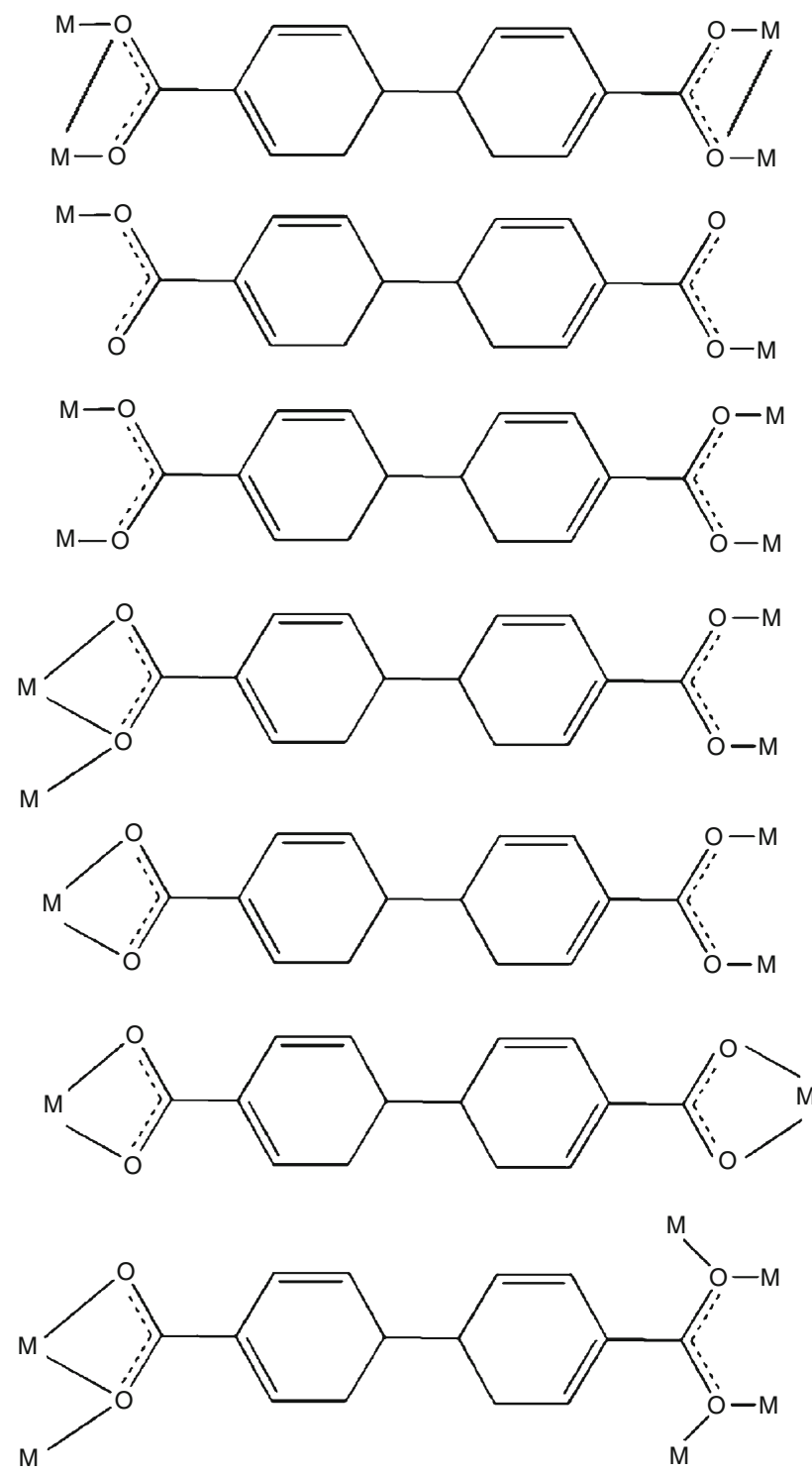

Fig. 1 Possible coordination modes of $\operatorname{bpdc}^{2-}$ ligand

several conditions (air and nitrogen atmosphere) and thermal effects related to these decomposition processes of analyzed compounds.

\section{Experimental}

Synthesis

The complexes of lanthanide(III) with biphenyl-4,4'-dicarboxylic acid were prepared by adding hot aqueous solutions of sodium biphenyl-4,4'-dicarboxylate (bpdc) dropwise ( $\mathrm{pH}=$ 6.5) into the hot aqueous solution of rare earth chlorides ( $\mathrm{pH}=4.5-6.0)$ while stirring continuously. In the case of cerium(III), the nitrate solution was used. The precipitates were filtered, washed with hot water and dried at $30{ }^{\circ} \mathrm{C}$ to a constant mass. All reagents were used in the commercial form. Lanthanide oxides (99.9\% purity) and biphenyl-4,4'-dicarboxylic acid (97\% purity) were produced by Aldrich.

Measurement methods

The contents of carbon and hydrogen were determined on the basis of elemental analyses by using a CHN 2400 Perkin Elmer instrument. The content of $\mathrm{Ln}^{3+}$ was established on the strength of thermogravimetric analyses (TG curves) using the oxalic method, which consists in calculating the metal contents from the obtained residues as the products of thermal decomposition of analyzed complexes. The results are presented in Table 1.

The complexes were identified on the basis of the FT-IR spectra recorded over the range $4,000-400 \mathrm{~cm}^{-1}$ in $\mathrm{KBr}$ disks using a FT-IR 1725X Perkin Elmer spectrometer.

All lanthanide compounds were also examined by the FT-Raman spectroscopy in the range $150-3,200 \mathrm{~cm}^{-1}$ using a Via Reflex Renishaw Raman spectrometer. The samples were irradiated using argon ionization $(\lambda=514 \mathrm{~nm})$ or semiconductor $(\lambda=785 \mathrm{~nm})$ laser with 10 min exposure time.

The thermal stability and decomposition of the prepared complexes in air were determined with the aid of Setsys $16 / 18$, recording TG, differential scanning calorimetry (DSC), and DTG curves. The sample (7-8 $\mathrm{mg}$ ) was heated in the $\mathrm{Al}_{2} \mathrm{O}_{3}$ crucible at $30-750{ }^{\circ} \mathrm{C}$ in flowing air atmosphere with a heating rate of $5{ }^{\circ} \mathrm{C} \mathrm{min}{ }^{-1}$. The sample of $\mathrm{La}(\mathrm{III})$ and $\mathrm{Lu}(\mathrm{III})$ complexes was heated between 30 and $1,000{ }^{\circ} \mathrm{C}$ in dynamic air atmosphere with a heating rate $10{ }^{\circ} \mathrm{C} \min ^{-1}$. Products of decomposition were calculated from the TG curves.

FT-IR spectra of gaseous products of thermal decomposition were registered on a Netzsch TG 209 instrument coupled to a Brucker FT-IR IFS66 spectrometer. The sample of gadolinium(III) and terbium(III) complexes was heated in dynamic argon atmosphere using a ceramic crucible and heating with a rate of $15^{\circ} \mathrm{C} \mathrm{min}-1$ up to $1,000{ }^{\circ} \mathrm{C}$.

The X-ray diffraction patterns were taken on a HZG-4 (Carl Zeiss, Jena) diffractometer $\left(2 \theta=3-70^{\circ}\right.$ with a step equal to $0.05^{\circ}$ ) at ambient temperature. The XRAYAN program was used for determining positions and peak intensities. Pattern indexing was carried out with the PC version of TREOR program [21].

\section{Results and discussion}

Characterization and XRD studies

Bpdcs of lanthanide(III) were obtained as polycrystalline hydrates of typical color for $\mathrm{Ln}^{3+}$ ions. Based on the 
Table 1 The elemental analysis data of bpdes obtained under conventional conditions (bpdc $=\mathrm{C}_{14} \mathrm{H}_{8} \mathrm{O}_{4}^{2-}$ )

\begin{tabular}{|c|c|c|c|c|c|c|}
\hline \multirow[t]{2}{*}{ Complex } & \multicolumn{2}{|l|}{$\mathrm{C} / \%$} & \multicolumn{2}{|l|}{$\mathrm{H} / \%$} & \multicolumn{2}{|l|}{$\mathrm{Ln} / \%$} \\
\hline & Found & Calc. & Found & Calc. & Found & Calc. \\
\hline $\mathrm{La}_{2}(\mathrm{bpdc})_{3} \cdot 4 \mathrm{H}_{2} \mathrm{O}$ & 46.95 & 47.08 & 2.96 & 2.99 & 26.02 & 25.95 \\
\hline $\mathrm{Ce}_{2}(\mathrm{bpdc})_{3} \cdot 4 \mathrm{H}_{2} \mathrm{O}$ & 46.73 & 46.97 & 2.94 & 2.98 & 25.79 & 26.12 \\
\hline $\mathrm{Pr}_{2}(\mathrm{bpdc})_{3} \cdot 4 \mathrm{H}_{2} \mathrm{O}$ & 47.44 & 46.91 & 2.93 & 2.98 & 26.01 & 26.67 \\
\hline $\mathrm{Nd}_{2}(\mathrm{bpdc})_{3} \cdot 5 \mathrm{H}_{2} \mathrm{O}$ & 45.83 & 45.85 & 3.01 & 3.09 & 25.87 & 26.24 \\
\hline $\mathrm{Sm}_{2}(\mathrm{bpdc})_{3} \cdot 4 \mathrm{H}_{2} \mathrm{O}$ & 45.82 & 46.09 & 2.90 & 2.93 & 28.49 & 27.50 \\
\hline $\mathrm{Eu}_{2}(\mathrm{bpdc})_{3} \cdot 4 \mathrm{H}_{2} \mathrm{O}$ & 45.57 & 45.96 & 2.88 & 2.92 & 27.67 & 27.72 \\
\hline $\mathrm{Gd}_{2}(\mathrm{bpdc})_{3} \cdot 6 \mathrm{H}_{2} \mathrm{O}$ & 44.38 & 44.09 & 3.11 & 3.15 & 27.42 & 27.51 \\
\hline $\mathrm{Tb}_{2}(\mathrm{bpdc})_{3} \cdot 6 \mathrm{H}_{2} \mathrm{O}$ & 43.62 & 43.96 & 3.13 & 3.14 & 26.80 & 27.72 \\
\hline $\mathrm{Dy}_{2}(\mathrm{bpdc})_{3} \cdot 6 \mathrm{H}_{2} \mathrm{O}$ & 43.31 & 43.69 & 3.07 & 3.12 & 28.35 & 28.17 \\
\hline $\mathrm{Ho}_{2}(\mathrm{bpdc})_{3} \cdot 6 \mathrm{H}_{2} \mathrm{O}$ & 43.08 & 43.50 & 3.09 & 3.11 & 27.57 & 28.47 \\
\hline $\mathrm{Er}_{2}(\mathrm{bpdc})_{3} \cdot 5 \mathrm{H}_{2} \mathrm{O}$ & 43.60 & 44.01 & 2.90 & 2.97 & 28.71 & 29.21 \\
\hline $\mathrm{Tm}_{2}(\mathrm{bpdc})_{3} \cdot 5 \mathrm{H}_{2} \mathrm{O}$ & 43.72 & 43.88 & 2.91 & 2.96 & 29.10 & 29.42 \\
\hline $\mathrm{Yb}_{2}(\mathrm{bpdc})_{3} \cdot 4 \mathrm{H}_{2} \mathrm{O}$ & 43.98 & 44.26 & 2.76 & 2.81 & 30.26 & 30.39 \\
\hline $\mathrm{Lu}_{2}(\mathrm{bpdc})_{3} \cdot 4 \mathrm{H}_{2} \mathrm{O}$ & 44.04 & 44.11 & 2.75 & 2.80 & 31.34 & 30.63 \\
\hline
\end{tabular}

analytical (Table 1) and TG data their formulae were defined as: $\mathrm{Ln}_{2}(\mathrm{bpdc})_{3} \cdot n \mathrm{H}_{2} \mathrm{O}$ where bpdc is the biphenyl$4,4^{\prime}$-dicarboxylate ligand $\left(\mathrm{C}_{12} \mathrm{H}_{5}(\mathrm{COO})_{2}^{2-}\right) ; \mathrm{Ln}$ is $\mathrm{La}-\mathrm{Lu}$ and $n=4$ for La-Pr, Sm, Eu, Yb and Lu; $n=5$ for $\mathrm{Nd}, \mathrm{Er}$ and Tm; $n=6$ for $\mathrm{Gd}-\mathrm{Ho}$.

The X-ray diffraction patterns indicate that all lanthanide(III) bpdes form crystalline powders. The majority of the investigated complexes crystallize in the triclinic crystal system (La-Dy, Tm and Yb), whereas the monoclinic cell parameters were ascribed to $\mathrm{Ho}, \mathrm{Er}$, and $\mathrm{Lu}$ compounds. The number of water molecules does not affect the crystal structures of the analyzed complexes (Table 2). In the series of lanthanide bpdcs three groups of isostructural complexes can be differentiated: (1) La(III)Tb(III), (2) Dy(III) and Ho(III), (3) the complexes Er(III)$\mathrm{Lu}(\mathrm{III})$. Figure 2 presents the X-ray pattern diffractions of neodymium(III), holmium(III), and lutetium(III) complexes as representatives of the above-mentioned isostructural series. As can be seen from the XRD patterns, the most intensive line is concurrently the first, regardless of the membership of concrete lanthanide ions to one of isostructural series. In the case of the XRD pattern of $\mathrm{Nd}_{2}$ (bpdc) $)_{3} \cdot 5 \mathrm{H}_{2} \mathrm{O}$, the lowest number of sharp peaks is observed. This fact certainly indicates that the first series of isostructural complexes ( $\mathrm{La}(\mathrm{III})-\mathrm{Tb}(\mathrm{III})$ ) forms complexes of lowest symmetry.

Table 2 The unit cell parameters for polycrystalline series of bpdcs (bpdc $=\mathrm{C}_{14} \mathrm{H}_{8} \mathrm{O}_{4}^{2-}$ )

\begin{tabular}{llrrrrrrr}
\hline Complexes & Crystal system & \multicolumn{1}{c}{$a / \AA$} & \multicolumn{1}{c}{$b / \AA$} & $c / \AA$ & $\alpha /^{\circ}$ & \multicolumn{1}{c}{$\beta /^{\circ}$} & $\gamma /{ }^{\circ}$ & $V_{\text {olume } / \AA^{-3}}$ \\
\hline $\mathrm{La}_{2}(\mathrm{bpdc})_{3} \cdot 4 \mathrm{H}_{2} \mathrm{O}$ & Triclinic & 8.61 & 10.88 & 17.87 & 87.95 & 57.91 & 57.80 & 1127 \\
$\mathrm{Ce}_{2}(\mathrm{bpdc})_{3} \cdot 4 \mathrm{H}_{2} \mathrm{O}$ & Triclinic & 9.16 & 8.86 & 16.44 & 101.42 & 120.27 & 74.18 & 1105 \\
$\mathrm{Pr}_{2}(\mathrm{bpdc})_{3} \cdot 4 \mathrm{H}_{2} \mathrm{O}$ & Triclinic & 7.95 & 14.60 & 18.80 & 48.28 & 73.18 & 65.35 & 1479 \\
$\mathrm{Nd}_{2}(\mathrm{bpdc})_{3} \cdot 5 \mathrm{H}_{2} \mathrm{O}$ & Triclinic & 8.57 & 14.13 & 23.02 & 141.77 & 90.67 & 85.91 & 1715 \\
$\mathrm{Sm}_{2}(\mathrm{bpdc})_{3} \cdot 4 \mathrm{H}_{2} \mathrm{O}$ & Triclinic & 6.57 & 13.17 & 17.16 & 122.31 & 78.26 & 91.18 & 1223 \\
$\mathrm{Eu}_{2}(\mathrm{bpdc})_{3} \cdot 4 \mathrm{H}_{2} \mathrm{O}$ & Triclinic & 7.84 & 14.29 & 16.06 & 114.16 & 115.65 & 57.66 & 1332 \\
$\mathrm{Gd}_{2}(\mathrm{bpdc})_{3} \cdot 6 \mathrm{H}_{2} \mathrm{O}$ & Triclinic & 12.41 & 11.86 & 19.68 & 53.77 & 49.54 & 53.81 & 1674 \\
$\mathrm{~Tb}_{2}(\mathrm{bpdc})_{3} \cdot 6 \mathrm{H}_{2} \mathrm{O}$ & Triclinic & 9.63 & 13.27 & 18.01 & 128.84 & 108.98 & 55.32 & 1472 \\
$\mathrm{Dy}_{2}(\mathrm{bpdc})_{3} \cdot 6 \mathrm{H}_{2} \mathrm{O}$ & Triclinic & 7.40 & 14.90 & 15.92 & 79.10 & 83.15 & 106.40 & 1626 \\
$\mathrm{Ho}_{2}(\mathrm{bpdc})_{3} \cdot 6 \mathrm{H}_{2} \mathrm{O}$ & Monoclinic & 14.00 & 13.39 & 9.58 & 90.00 & 96.82 & 90.00 & 1782 \\
$\mathrm{Er}_{2}(\mathrm{bpdc})_{3} \cdot 5 \mathrm{H}_{2} \mathrm{O}$ & Monoclinic & 15.21 & 6.17 & 14.45 & 90.00 & 101.30 & 90.00 & 1330 \\
$\mathrm{Tm}_{2}(\mathrm{bpdc})_{3} \cdot 5 \mathrm{H}_{2} \mathrm{O}$ & Triclinic & 9.30 & 13.60 & 14.80 & 78.09 & 78.38 & 67.65 & 1678 \\
$\mathrm{Yb}_{2}(\mathrm{bpdc})_{3} \cdot 4 \mathrm{H}_{2} \mathrm{O}$ & Triclinic & 8.76 & 16.19 & 15.29 & 78.96 & 79.96 & 63.77 & 1900 \\
$\mathrm{Lu}_{2}(\mathrm{bpdc})_{3} \cdot 4 \mathrm{H}_{2} \mathrm{O}$ & Monoclinic & 17.18 & 7.57 & 15.82 & 90.00 & 115.27 & 90.00 & 1860 \\
\hline
\end{tabular}




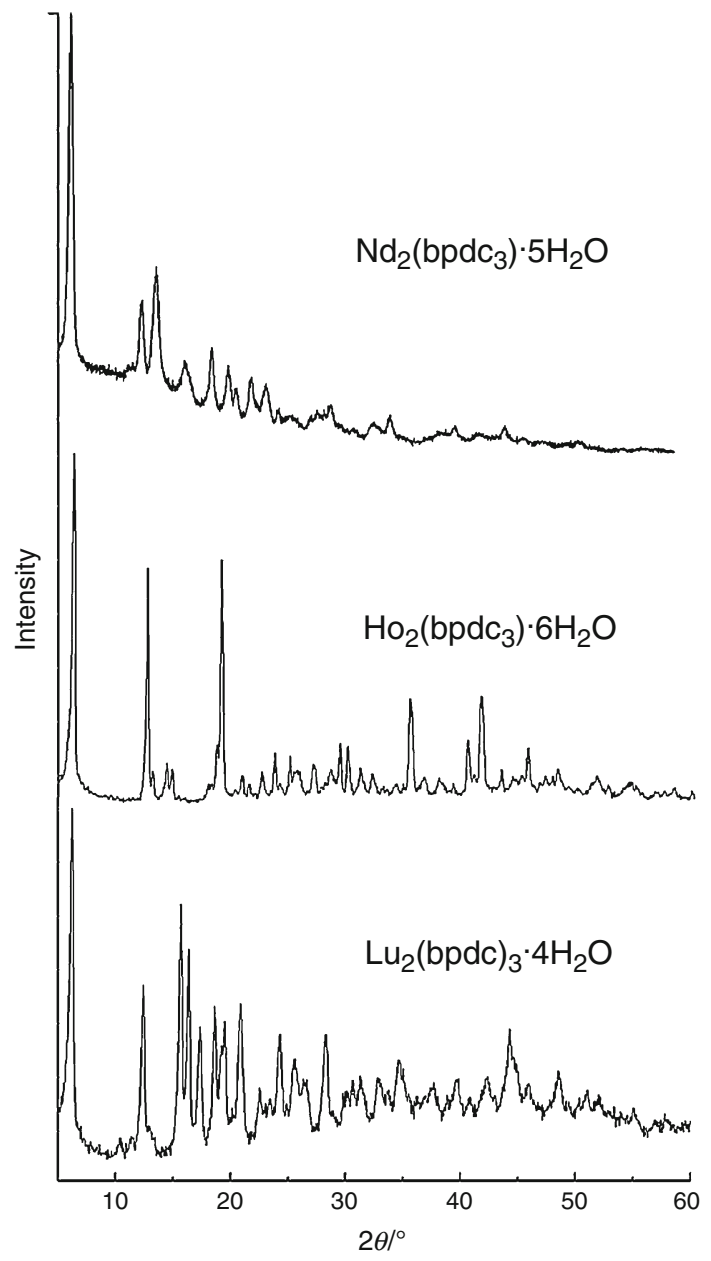

Fig. 2 X-ray diffraction patterns of representatives of isostructural series of lanthanide biphenyl-4,4'-dicarboxylates

\section{FT-IR and FT-Raman investigations}

All investigated lanthanide(III) bpdcs were characterized by FT-IR and FT-Raman spectroscopy exhibiting similar solid state spectra. The experimental FT-IR and FT-Raman spectra of free $\mathrm{H}_{2}$ bpdc ligand and its lanthanum(III), terbium(III), and lutetium(III) complexes are presented in Figs. 3 and 4. The symbols used denote the following: $v$ stands for the stretching vibrations; $\beta$ for the in-plane deformation modes; $\gamma$ for the out-of-plane bending modes, and $\mathrm{Ar}$ for aromatic carbon atoms vibrations. Replacement of the carboxylic groups' hydrogen with a metal ion brings about some characteristic changes in the FT-IR and FTRaman spectra of the metal complexes in comparison with those of free ligand. The most important change observed between the FT-IR spectra of acid and its salts is appearance of the asymmetric and symmetric stretching vibrations of carboxylate anion $v_{\mathrm{as}}\left(\mathrm{COO}^{-}\right)$and $v_{\mathrm{s}}\left(\mathrm{COO}^{-}\right)$in the spectra of lanthanide(III) complexes in the regions 1,580-1,576 and $1,441-1,402 \mathrm{~cm}^{-1}$, respectively, instead of very diagnostic

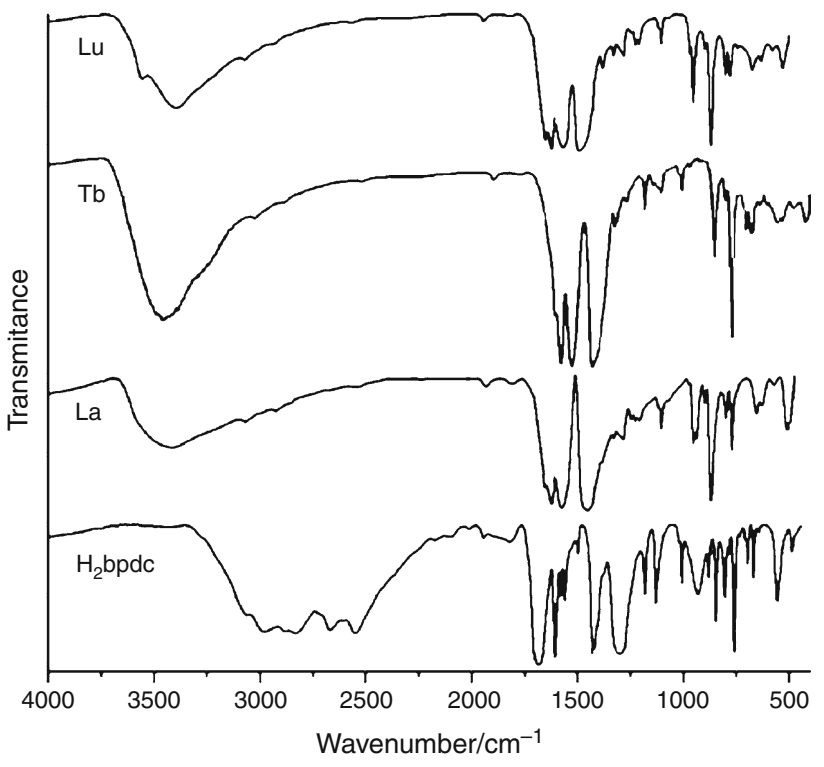

Fig. 3 Experimental FT-IR spectra of $\mathrm{H}_{2}$ bpdc ligand and its $\mathrm{La}(\mathrm{III})$, $\mathrm{Tb}(\mathrm{III})$, and $\mathrm{Lu}(\mathrm{III})$ complexes

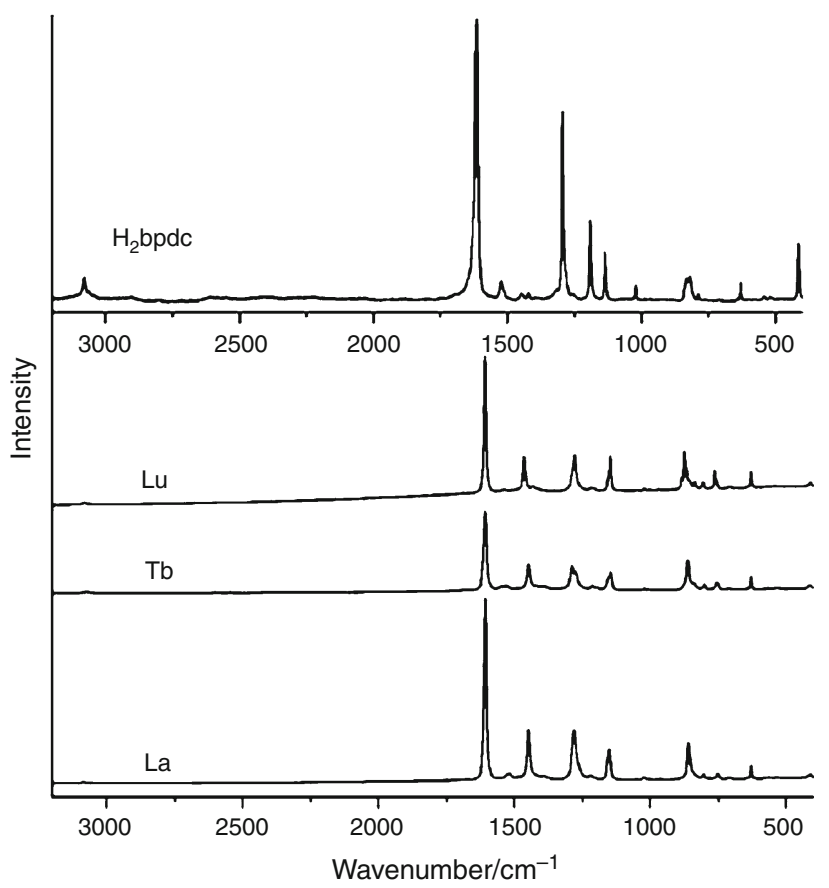

Fig. 4 Experimental FT-Raman spectra of $\mathrm{H}_{2}$ bpdc ligand and its $\mathrm{La}(\mathrm{III}), \mathrm{Tb}(\mathrm{III})$, and $\mathrm{Lu}(\mathrm{III})$ complexes

absorption bands derived from the stretching $v(\mathrm{C}=\mathrm{O})$ vibrations of carboxylic groups at $1,684 \mathrm{~cm}^{-1}$ observed in the FT-IR spectra of free ligand. Appearance of these absorption bands of $-\mathrm{COO}^{-}$groups proves that bpdc ligand is successfully coordinated by lanthanide ions in the studied complexes. Other significant changes connected with transformation of carboxylic groups into carboxylate anions are the absence of the other absorption bands which derived 
from the nonionized carboxylic groups of free acid at 1427 $[v(\mathrm{C}-\mathrm{O})], 1295[\beta(\mathrm{COH})]$, and $931 \mathrm{~cm}^{-1}[\gamma(\mathrm{COH})]$ confirm the complete deprotonation of acid. The presence of water molecules in the structures of the investigated complexes was confirmed by the broad absorbance band in the range $3,700-2,500 \mathrm{~cm}^{-1}$ characteristic of stretching vibrations of hydroxyl groups $v(\mathrm{OH})$ of hydrogen-bonded water molecules. The bands due to the metal-oxygen bond appear at $431-411 \mathrm{~cm}^{-1}$ for the whole series of complexes. Putting the metal ions into the structure of free ligand induces the differences in the density charge distribution in the newformed metal-ligand structure of complexes, which consequently also brings the insignificant changes connected with disappearance and shifting of the position of some typical aromatic bands derived from the biphenyl group, despite the fact that biphenyl system does not take part in the coordination process. Thus, the FT-Raman spectra of lanthanide(III) complexes were recorded and collated with the FT-IR spectra to make sure that faultless assignments of the individual absorption bands to suitable vibrations come from nonpolar atom groups, like aromatic carbon-carbon and carbon-hydrogen vibrations.
Thermal analysis (TG-DSC) in air

To investigate thermal stability and decomposition of the complexes under investigation, the TG analysis and the DSC were performed for the crystalline samples. All lanthanide(III) bpdcs are stable at ambient temperature but further heating leads to gradual decomposition (Fig. 5; Table 3). The thermal decomposition of hydrated investigated compounds in air proceeds in two principal stages, including dehydration process and degradation of anhydrous form of studied complexes. The first significant weight loss observed on the TG curves (Fig. 5) corresponds to the removal of water molecules from the structure of hydrated complexes. The dehydration enthalpies found for bpdes were in the range $83-306 \mathrm{~kJ} \mathrm{~mol}^{-1}$.

In the case of the complexes from cerium(III) to europium(III), ytterbium(III) and lutetium(III), heating over $30{ }^{\circ} \mathrm{C}$ initiates the one-step dehydration process, which takes place up to $150-220^{\circ} \mathrm{C}$. The TG curves in the aforementioned temperature range show loss of mass by about 6.57-7.24\%, which corresponds to the loss of four water molecules, whereas the TG profile of neodymium(III)
Fig. 5 TG and DSC curves of thermal decomposition in air atmosphere of $\mathrm{La}_{2}(\mathrm{bpdc})_{3} \cdot 4 \mathrm{H}_{2} \mathrm{O}$ (a), $\mathrm{Nd}_{2}(\mathrm{bpdc})_{3} \cdot 5 \mathrm{H}_{2} \mathrm{O}$ (c), and $\mathrm{Lu}_{2}$ (bpdc) $)_{3} \cdot 4 \mathrm{H}_{2} \mathrm{O}$ (e) down to augmentation of the range of dehydration process of abovementioned $\mathrm{La}(\mathbf{b}), \mathrm{Nd}(\mathbf{d})$ and Lu (f) complexes
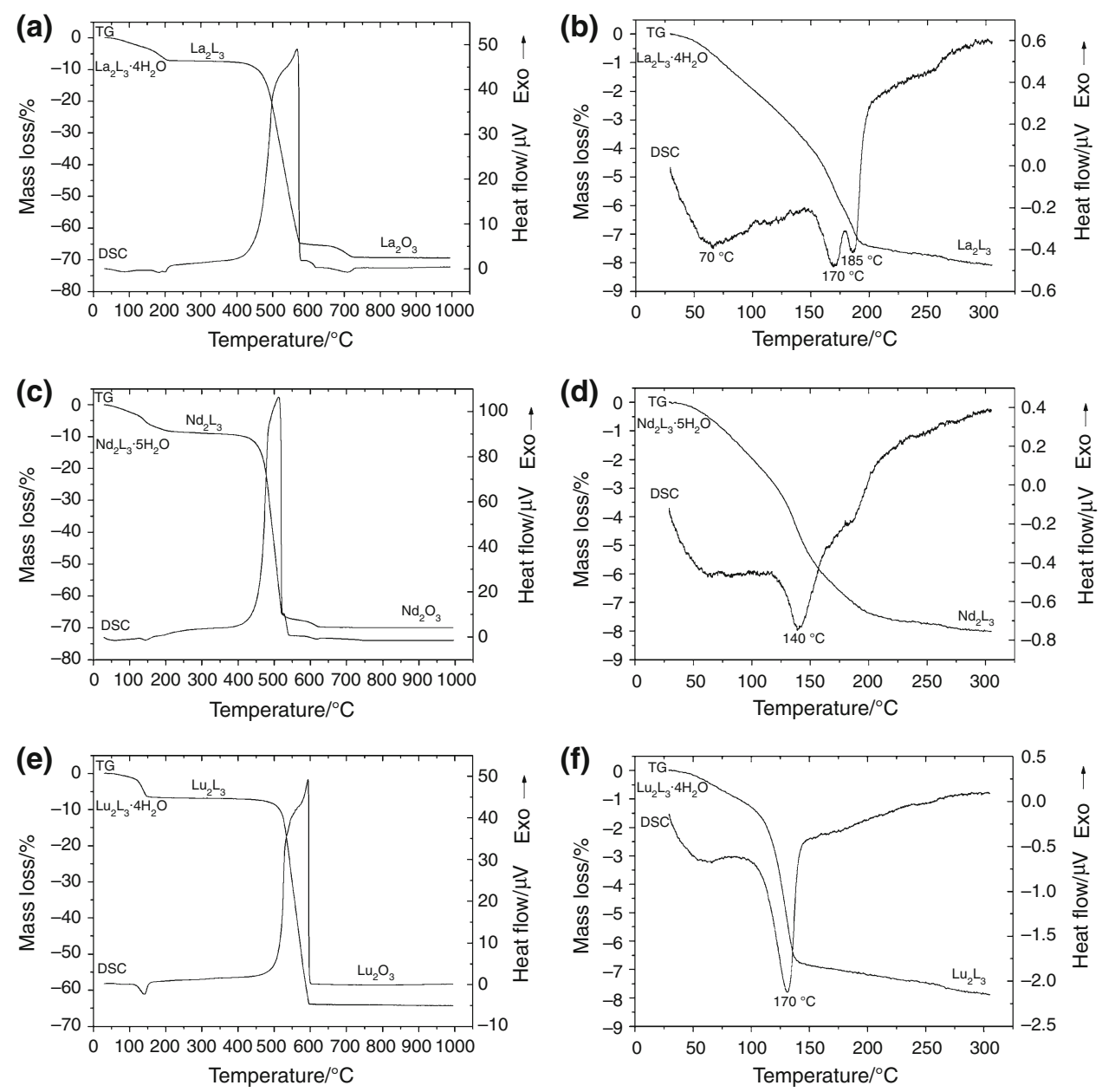
Table 3 Thermoanalytical data of lanthanide(III) bpdcs (air); $\mathrm{L}=\left(\mathrm{C}_{14} \mathrm{H}_{8} \mathrm{O}_{4}\right)^{2-}$

\begin{tabular}{|c|c|c|c|c|c|c|c|c|}
\hline \multirow[t]{2}{*}{ Complex } & \multirow[t]{2}{*}{$\Delta T_{1} /{ }^{\circ} \mathrm{C}$} & \multicolumn{2}{|c|}{ Mass loss $/ \%$} & \multirow[t]{2}{*}{ Endothermic effect/ $\mathrm{J} \mathrm{g}^{-1}$} & \multirow[t]{2}{*}{$\Delta T_{2} /{ }^{\circ} \mathrm{C}$} & \multicolumn{2}{|c|}{ Total mass loss $/ \%$} & \multirow[t]{2}{*}{ Final product } \\
\hline & & Calc. & Found & & & Calc. & Found & \\
\hline $\mathrm{La}_{2} \mathrm{~L}_{3} \cdot 4 \mathrm{H}_{2} \mathrm{O}$ & $30-220$ & 6.73 & 7.15 & 106 & $395-740$ & 69.56 & 69.49 & $\mathrm{La}_{2} \mathrm{O}_{3}$ \\
\hline $\mathrm{Ce}_{2} \mathrm{~L}_{3} \cdot 4 \mathrm{H}_{2} \mathrm{O}$ & $30-200$ & 6.71 & 7.19 & 83 & $310-440$ & 67.92 & 68.14 & $\mathrm{CeO}_{2}$ \\
\hline $\mathrm{Pr}_{2} \mathrm{~L}_{3} \cdot 4 \mathrm{H}_{2} \mathrm{O}$ & $30-205$ & 6.70 & 7.24 & 164 & $405-555$ & 68.31 & 68.58 & $\mathrm{Pr}_{6} \mathrm{O}_{11}$ \\
\hline $\mathrm{Nd}_{2} \mathrm{~L}_{3} \cdot 5 \mathrm{H}_{2} \mathrm{O}$ & $30-220$ & 8.19 & 8.39 & 185 & $395-640$ & 69.39 & 69.67 & $\mathrm{Nd}_{2} \mathrm{O}_{3}$ \\
\hline $\mathrm{Sm}_{2} \mathrm{~L}_{3} \cdot 4 \mathrm{H}_{2} \mathrm{O}$ & $30-200$ & 6.59 & 6.94 & 173 & $400-610$ & 68.11 & 67.79 & $\mathrm{Sm}_{2} \mathrm{O}_{3}$ \\
\hline $\mathrm{Eu}_{2} \mathrm{~L}_{3} \cdot 4 \mathrm{H}_{2} \mathrm{O}$ & $30-200$ & 6.57 & 6.83 & 227 & $350-625$ & 67.91 & 67.97 & $\mathrm{Eu}_{2} \mathrm{O}_{3}$ \\
\hline $\mathrm{Gd}_{2} \mathrm{~L}_{3} \cdot 6 \mathrm{H}_{2} \mathrm{O}$ & $30-80$ & 3.15 & 3.02 & 306 & $405-630$ & 68.29 & 68.39 & $\mathrm{Gd}_{2} \mathrm{O}_{3}$ \\
\hline $\mathrm{Gd}_{2} \mathrm{~L}_{3} \cdot 4 \mathrm{H}_{2} \mathrm{O}$ & $80-200$ & 6.30 & 6.11 & & & & & \\
\hline $\mathrm{Tb}_{2} \mathrm{~L}_{3} \cdot 6 \mathrm{H}_{2} \mathrm{O}$ & $30-90$ & 3.14 & 2.86 & 152 & $410-540$ & 67.39 & 67.68 & $\mathrm{~Tb}_{4} \mathrm{O}_{7}$ \\
\hline $\mathrm{Tb}_{2} \mathrm{~L}_{3} \cdot 4 \mathrm{H}_{2} \mathrm{O}$ & $90-160$ & 6.28 & 6.38 & & & & & \\
\hline $\mathrm{Dy}_{2} \mathrm{~L}_{3} \cdot 6 \mathrm{H}_{2} \mathrm{O}$ & $30-85$ & 3.12 & 3.20 & 285 & $440-560$ & 67.67 & 67.48 & $\mathrm{Dy}_{2} \mathrm{O}_{3}$ \\
\hline $\mathrm{Dy}_{2} \mathrm{~L}_{3} \cdot 4 \mathrm{H}_{2} \mathrm{O}$ & $85-145$ & 6.24 & 5.94 & & & & & \\
\hline $\mathrm{Ho}_{2} \mathrm{~L}_{3} \cdot 6 \mathrm{H}_{2} \mathrm{O}$ & $30-85$ & 3.11 & 3.23 & 260 & $440-565$ & 67.39 & 67.62 & $\mathrm{Ho}_{2} \mathrm{O}_{3}$ \\
\hline $\mathrm{Ho}_{2} \mathrm{~L}_{3} \cdot 4 \mathrm{H}_{2} \mathrm{O}$ & $85-155$ & 6.22 & 6.23 & & & & & \\
\hline $\mathrm{Er}_{2} \mathrm{~L}_{3} \cdot 5 \mathrm{H}_{2} \mathrm{O}$ & $30-110$ & 4.72 & 4.95 & 167 & $435-555$ & 66.60 & 66.40 & $\mathrm{Er}_{2} \mathrm{O}_{3}$ \\
\hline $\mathrm{Er}_{2} \mathrm{~L}_{3} \cdot 2 \mathrm{H}_{2} \mathrm{O}$ & $110-150$ & 3.14 & 3.01 & & & & & \\
\hline $\mathrm{Tm}_{2} \mathrm{~L}_{3} \cdot 5 \mathrm{H}_{2} \mathrm{O}$ & $30-100$ & 3.14 & 2.92 & 121 & $450-560$ & 66.40 & 66.24 & $\mathrm{Tm}_{2} \mathrm{O}_{3}$ \\
\hline $\mathrm{Tm}_{2} \mathrm{~L}_{3} \cdot 3 \mathrm{H}_{2} \mathrm{O}$ & $100-155$ & 4.70 & 4.67 & & & & & \\
\hline $\mathrm{Yb}_{2} \mathrm{~L}_{3} \cdot 4 \mathrm{H}_{2} \mathrm{O}$ & $30-150$ & 6.32 & 6.74 & 111 & $440-550$ & 65.39 & 65.54 & $\mathrm{Yb}_{2} \mathrm{O}_{3}$ \\
\hline $\mathrm{Lu}_{2} \mathrm{~L}_{3} \cdot 4 \mathrm{H}_{2} \mathrm{O}$ & $30-170$ & 6.30 & 6.57 & 124 & $440-605$ & 65.17 & 65.43 & $\mathrm{Lu}_{2} \mathrm{O}_{3}$ \\
\hline
\end{tabular}

$\Delta T_{1}$, temperature range of dehydration process; $\Delta T_{2}$, temperature range of decomposition of anhydrous complexes to oxides

compound demonstrates the weight loss of $8.39 \%$, which is associated with elimination of five water molecules. Although, only one obvious weight loss is observed, the shape of peaks on the DSC curves indicates that water molecules are released in the overlapping stages. The evident mass loss is accompanied by the endothermic effect with the peak top at $110{ }^{\circ} \mathrm{C}$ (for $\mathrm{Nd}$ and $\mathrm{Eu}$ ), $115^{\circ} \mathrm{C}$ (for $\mathrm{Sm}$ ), $130{ }^{\circ} \mathrm{C}$ (for $\mathrm{Yb}$ and $\mathrm{Lu}$ ), $140{ }^{\circ} \mathrm{C}$ (for $\mathrm{Pr}$ ), and $150{ }^{\circ} \mathrm{C}$ (for $\mathrm{Ce}$ ) (Fig. 5).

The dehydration process in bpdes from gadolinium(III) to thulium(III) hydrates proceeds in two steps and represents the loss of two and remaining (four or three) water molecules, respectively. In comparison with one-stage dehydration, the dehydration process for hexa- and pentahydrates in question also begins at $30{ }^{\circ} \mathrm{C}$ and runs to the relatively lower temperature range $150-160{ }^{\circ} \mathrm{C}$ (except $\mathrm{Gd}_{2}$ (bpdc) $)_{3} \cdot 6 \mathrm{H}_{2} \mathrm{O}$, where dehydration increases up to $200{ }^{\circ} \mathrm{C}$ ). The first dehydration step observed on the TG curves is characterized by the weight loss in the range 2.86-4.95\%. These mass losses are related to the endothermic effect (observed on the DSC curves) with the maxima at $70{ }^{\circ} \mathrm{C}$ (Gd(III) and Dy(III) complexes), $75{ }^{\circ} \mathrm{C}$ ( $\mathrm{Tb}(\mathrm{III})$, and $\mathrm{Ho}(\mathrm{III})$ compounds), $85^{\circ} \mathrm{C}$ (Tm(III) complex) and $95^{\circ} \mathrm{C}(\mathrm{Er}$ (III) compound). The remaining water molecules (four or three) are evolved in the temperature range $85-160{ }^{\circ} \mathrm{C}$ (Table 3 ). The maxima of endothermic effects attributed to the second step of dehydration process appear at $105^{\circ} \mathrm{C}(\mathrm{Gd}(\mathrm{III}), \mathrm{Dy}(\mathrm{III})$ and, Ho(III) complexes), $115^{\circ} \mathrm{C}\left(\mathrm{Tb}(\mathrm{III})\right.$ compound) and $130{ }^{\circ} \mathrm{C} \quad(\mathrm{Er}(\mathrm{III})$ and Tm(III) complexes) (Fig. 5).

Removal of water molecules in the $\mathrm{La}_{2} \mathrm{bpdc}_{3} \cdot 4 \mathrm{H}_{2} \mathrm{O}$ complex proceeds in a more complicated way. The TG curve shows only one appreciable dehydration step, while DSC profile shows not clearly separated three endothermic peak tops at 70,170 , and $185^{\circ} \mathrm{C}$ which permit us to presume stepwise dehydration (Fig. 5a, b).

After the complete removal of water molecules from the hydrated complexes the anhydrous compounds $\left(\mathrm{Ln}_{2} \mathrm{bpdc}_{3}\right)$ are formed. The TG curves show plateau up to $310-450{ }^{\circ} \mathrm{C}$ which indicates a wide range of stability of anhydrous compounds. On further heating, the anhydrous compounds decompose directly to suitable oxides $\left(\mathrm{CeO}_{2}, \mathrm{Pr}_{6} \mathrm{O}_{11}\right.$, $\mathrm{Tb}_{4} \mathrm{O}_{7}$, and $\left.\mathrm{Ln}(\mathrm{Dy}-\mathrm{Lu})_{2} \mathrm{O}_{3}\right)$. The temperature range of beginning of oxides formation is about $540-605{ }^{\circ} \mathrm{C}$. The temperature of establishing of $\mathrm{CeO}_{2}$ is much lower and it reaches approximately $440{ }^{\circ} \mathrm{C}$. In the case of the $\mathrm{La}(\mathrm{III})$ complex and compounds from $\mathrm{Nd}$ (III) to $\mathrm{Gd}$ (III) the corresponding oxides are formed by various intermediate forms. The temperature of oxides formation is higher than that of direct oxide formation and changes from $610{ }^{\circ} \mathrm{C}$ for $\mathrm{Sm}_{2} \mathrm{O}_{3}$, to $740{ }^{\circ} \mathrm{C}$ for $\mathrm{La}_{2} \mathrm{O}_{3}$. The DSC curve indicates that the decomposition of organic ligand is connected with a 
very strong exothermic effect with the peak top near $500{ }^{\circ} \mathrm{C}\left(490-540{ }^{\circ} \mathrm{C}\right)$. In the case of cerium(III) and europium(III) complexes, the exothermic peak tops occur at 400 and $425{ }^{\circ} \mathrm{C}$, respectively (Table 3).

\section{TG-FT-IR analysis in argon}

The simultaneous TG analysis in argon coupled with the FT-IR spectroscopy was performed for the crystalline sample of $\mathrm{Tb}_{2}$ bpdc $_{3} \cdot 6 \mathrm{H}_{2} \mathrm{O}$ as a complement to the thermal analysis obtained in air. This measurement technique enables determination of the way of complexes decomposition in atmosphere without oxygen and identification of the emitted gaseous products, which evolved during their thermal degradation. The mode of thermal decomposition of the analyzed complex in argon and in air atmosphere in the whole temperature range is similar (Fig. 6). As follows from Fig. 6, one noticeable difference, found on the thermal graphs obtained in argon, is the temperature of beginning of degradation of the organic ligand, which is shifted toward higher temperature by $100{ }^{\circ} \mathrm{C}\left(510^{\circ} \mathrm{C}\right)$, compared to the thermal analysis performed in air. From the obtained results, it can be stated with type of flowing gases does not affect the pathway of the dehydration process, the increasing thermal stability of the anhydrous form of the studied complexes. The line plot of the FT-IR spectra of the leaked gases for $\mathrm{Tb}_{2} \mathrm{bpdc}_{3} \cdot 6 \mathrm{H}_{2} \mathrm{O}$ are given
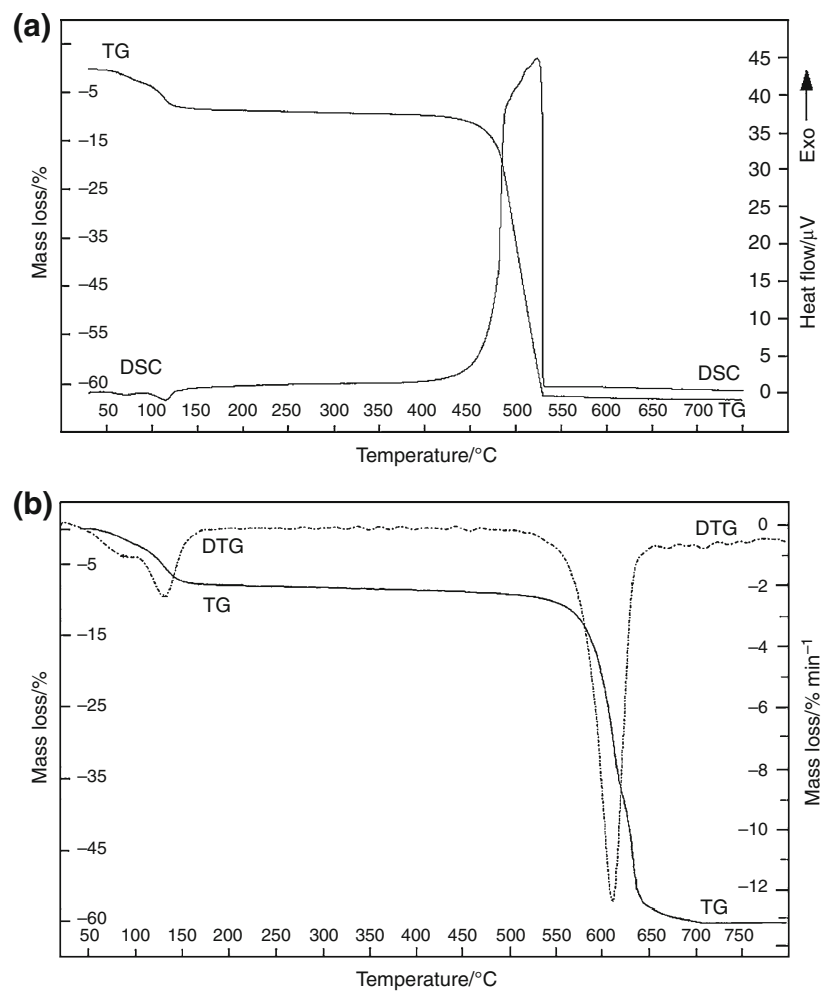

Fig. 6 TG, DSC and DTG curves of decomposition process of $\mathrm{Tb}_{2}(\mathrm{bpdc})_{3} \cdot 6 \mathrm{H}_{2} \mathrm{O}$ in air (a) and in argon (b) atmosphere

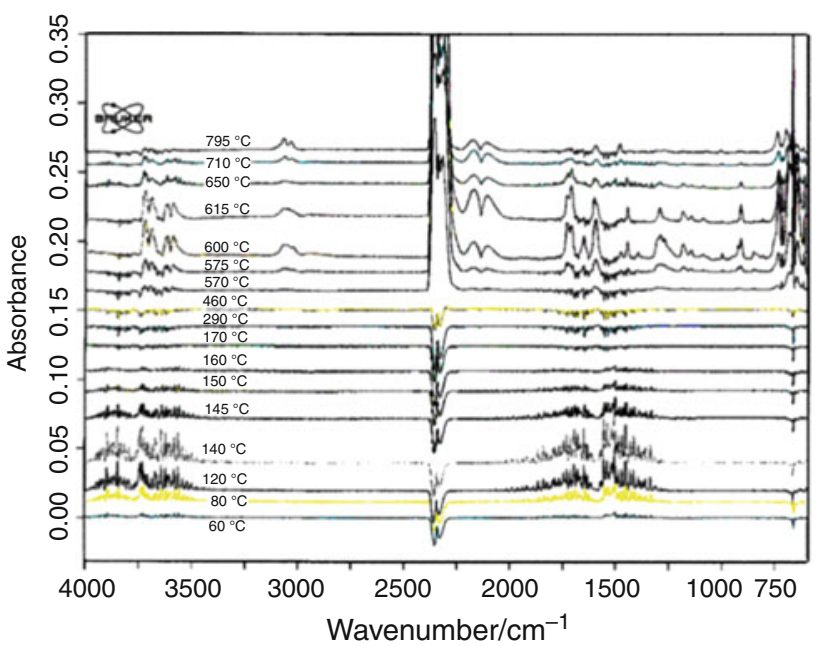

Fig. 7 Line plot of FT-IR spectra of the evolved gases for $\mathrm{Tb}_{2}\left(\mathrm{C}_{14} \mathrm{H}_{8} \mathrm{O}_{4}\right)_{3} \cdot 6 \mathrm{H}_{2} \mathrm{O}$

in Fig. 7. The FT-IR spectra recorded in the range of $50-170{ }^{\circ} \mathrm{C}$ show the absorption bands in the wavenumbers: $4,000-3,500$ and $1,900-1,300 \mathrm{~cm}^{-1}$ attributed to the stretching and deformation vibrations of hydroxyl groups $v(\mathrm{O}-\mathrm{H})$ from water molecules. Further heating up to about $510{ }^{\circ} \mathrm{C}$ does not cause release of any gaseous products that is characteristic of formation of stable anhydrous complex. Over this temperature, characteristic double bands of absorbed $\mathrm{CO}_{2}$ molecules at $2365,2315 \mathrm{~cm}^{-1}$ and those in the range $750-600 \mathrm{~cm}^{-1}$ are observed due to the degradation of $\mathrm{Tb}_{2} \mathrm{bpdc}_{3}$ compound. At a higher temperature $\left(575{ }^{\circ} \mathrm{C}\right)$, the molecules of carbon monoxide are released and their characteristic double-band with the maxima at 2160, $2105 \mathrm{~cm}^{-1}$ are detected. Around $600{ }^{\circ} \mathrm{C}$ the weak absorption bands at 3080,3040 , and $1300-850 \mathrm{~cm}^{-1}$ corresponding to the stretching and deformation vibrations of $v(\mathrm{C}-\mathrm{H})$ groups come from hydrocarbons [22-27].

\section{Conclusions}

In conclusion, a hydrated polycrystalline series of lanthanide complexes with biphenyl-4,4'-dicarboxylic acid was synthesized by means of the conventional precipitation method. The powder X-ray analysis revealed that they belong to three isostructural groups. The complexes are stable at room temperature, but heating causes one or two steps release of water molecules. After removal of all solvent molecules, the stable intermediate compounds $\mathrm{Ln}_{2} \mathrm{bpdc}_{3}$ are formed. The anhydrous complexes decompose directly or through intermediate forms to corresponding oxides. The modes of decomposition have been confirmed by the TG-FT-IR study and schematically proceed as follows: 
- tetrahydrated complexes:

(a) $\mathrm{Ln}_{2} \mathrm{bpdc}_{3} \cdot 4 \mathrm{H}_{2} \mathrm{O} \rightarrow \mathrm{Ln}_{2} \mathrm{bpdc}_{3} \rightarrow \mathrm{Ln}_{2} \mathrm{O}_{3}$, where $\mathrm{Ln}=\mathrm{La}, \mathrm{Sm}, \mathrm{Eu}, \mathrm{Yb}, \mathrm{Lu} ; \mathrm{Ce}_{2} \mathrm{bpdc}_{3} \cdot 4 \mathrm{H}_{2} \mathrm{O} \rightarrow$ $\mathrm{Ce}_{2} \mathrm{bpdc}_{3} \rightarrow 2 \mathrm{CeO}_{2} ; \quad 3\left[\mathrm{Pr}_{2} \mathrm{bpdc}_{3} \cdot 4 \mathrm{H}_{2} \mathrm{O}\right] \rightarrow 3 \mathrm{Pr}_{2}$ $\mathrm{bpdc}_{3} \rightarrow \mathrm{Pr}_{6} \mathrm{O}_{11}$;

- pentahydrated complexes:
(a) $\mathrm{Nd}_{2} \mathrm{bpdc}_{3} \cdot 5 \mathrm{H}_{2} \mathrm{O} \rightarrow \mathrm{Nd}_{2} \mathrm{bpdc}_{3} \rightarrow \mathrm{Nd}_{2} \mathrm{O}_{3}$;
(b) $\mathrm{Er}_{2} \mathrm{bpdc}_{3} \cdot 5 \mathrm{H}_{2} \mathrm{O} \rightarrow$
$\mathrm{Er}_{2} \mathrm{bpdc}_{3} \cdot 2 \mathrm{H}_{2} \mathrm{O} \rightarrow \mathrm{Er}_{2} \mathrm{bpdc}_{3} \rightarrow \mathrm{Er}_{2} \mathrm{O}_{3}$;
(c) $\mathrm{Tm}_{2} \mathrm{bpdc}_{3} \cdot 5 \mathrm{H}_{2} \mathrm{O} \rightarrow$
$\mathrm{Tm}_{2} \mathrm{bpdc}_{3} \cdot 3 \mathrm{H}_{2} \mathrm{O} \rightarrow \mathrm{Tm}_{2} \mathrm{bpdc}_{3} \rightarrow \mathrm{Tm}_{2} \mathrm{O}_{3}$;

- hexahydrated compound:

(a) $\mathrm{Ln}_{2} \mathrm{bpdc}_{3} \cdot 6 \mathrm{H}_{2} \mathrm{O} \rightarrow \mathrm{Ln}_{2} \mathrm{bpdc}_{3} \cdot 4 \mathrm{H}_{2} \mathrm{O} \rightarrow \mathrm{Ln}_{2} \mathrm{bpc}_{3}$ $\rightarrow \mathrm{Ln}_{2} \mathrm{O}_{3}$, where $\mathrm{Ln}=\mathrm{Gd}$, Dy, Ho; $2\left[\mathrm{~Tb}_{2} \mathrm{bpdc}_{3}\right.$. $\left.6 \mathrm{H}_{2} \mathrm{O}\right] \rightarrow 2\left[\mathrm{~Tb}_{2} \mathrm{bpdc}_{3} \cdot 4 \mathrm{H}_{2} \mathrm{O}\right] \rightarrow 2 \mathrm{~Tb}_{2} \mathrm{bpdc}_{3} \rightarrow$ $\mathrm{Tb}_{4} \mathrm{O}_{7}$.

Open Access This article is distributed under the terms of the Creative Commons Attribution License which permits any use, distribution, and reproduction in any medium, provided the original author(s) and the source are credited.

\section{References}

1. Kitagawa S, Matsuda R. Chemistry of coordination space of porous coordination polymers. Coord Chem Rev. 2007;251: 2490-509.

2. Yaghi OM, O'Keeffe M, Ockwig NW, Chae HK, Eddaoudi M, Kim J. Reticular synthesis and the design of new materials. Nature. 2003;423:705-14.

3. Neofotistou E, Malliakas CD, Trikalitis PN. Unprecedented sulfone-functionalized metal-organic frameworks and gas-sorption properties. Chem Eur J. 2009;15:4523-7.

4. Wang SN, Xing H, Li YZ, Bai J, Pan Y, Scheer M, You XZ. 2D and $3 \mathrm{D}$ cadmium(II) coordination polymers from a flexible tripodal ligand of 1,3,5-tris(carboxymethoxy)benzene and bidentate pyridyl-containing ligands with three-, eight- and ten-connected topologies. Eur J Inorg Chem. 2006;3041-53.

5. Lan YQ, Wang XL, Li SL, Su ZM, Shao KZ, Wang EB. An unprecedented $(6,8)$-connected self-penetrating network based on two distinct zinc clusters. Chem Commun. 2007;4863-5.

6. Wang XL, Qin C, Wang EB, Su ZM, Xu L, Batten SR. An unprecedented eight-connected self-penetrating network based on pentanuclear zinc cluster building blocks. Chem Commun. 2005; 4789-91.

7. Han YF, Zhou XH, Zheng YX, Shen Z, Song Y, You XZ. Syntheses, structures, photoluminescence, and magnetic properties of nanoporous 3D lanthanide coordination polymers with $4,4^{\prime}$-biphenyldicarboxylate ligand. CrystEngComm. 2008;10:1237-42.

8. Pan L, Ching N, Huang X, Li J. Reactions and reactivity of Cobpdc coordination polymers ( $b p d c=4,4^{\prime}$-biphenyldicarboxylate). Inorg Chem. 2000;39:5333-40.

9. Wang YB, Zhuang WJ, Jin LP, Lu SZ. Solvothermal synthesis and structures of lanthanide-organic sandwich coordination polymers with 4,4'-biphenyldicarboxylic acid. J Mol Struct. 2004;705:21-7.
10. Hu R, Cai H, Luo J. Synthesis, structure and luminescent property of a pillared-layer coordination polymer $[\mathrm{Pb}(\mathrm{BPDC})]\left(\mathrm{BPDC}=4,4^{\prime}\right.$ biphenyldicarboxylate). Inorg Chem Commun. 2011;14:433-6.

11. Yu B, Wang XQ, Kou HZ, Shen GQ, Shen DZ. Poly[[diaquasa marium(III)]- $\mu_{3}$-(biphenyl-4,4'-dicarboxylato)- $\mu_{3}-\left(4^{\prime}\right.$-carboxylbip henyl-4-carboxylato)]. Acta Crystallogr. 2006;E62:m3078-9.

12. Guo X, Zhu G, Fang Q, Xue M, Tian G, Sun J, Li X, Qiu S. Synthesis, structure and luminescent properties of rare earth coordination polymers constructed from paddle-wheel building blocks. Inorg Chem. 2005;44:3850-5.

13. Yuen T, Lin CL, Zan JA, Pan L, Li J. Magnetic properties of a metal-organic chain system $\left[\mathrm{Co}(\mathrm{bpdc})\left(\mathrm{H}_{2} \mathrm{O}\right)_{2}\right] \cdot \mathrm{H}_{2} \mathrm{O}(\mathrm{bpdc}=\mathrm{bi}-$ phenyldicarboxylate). J Appl Phys. 2005;97:10B315-1-3.

14. Long LS, Ren YP, Ma LH, Jiang YB, Huang RB, Zheng LS. A unique three-dimensional coordination polymer constructed from 4,4'-biphenyldicarboxylate and zinc(II). Inorg Chem Commun. 2003;6:690-3.

15. Liang Y, Hong M, Cao R, Weng J, Su W. Hydrothermal synthesis and characterization of the coordination polymer [ $\mathrm{Zn}(\mathrm{bbdc})$ $\left.\left(\mathrm{H}_{2} \mathrm{O}\right)\right]_{n}\left(\right.$ bbdc $=4,4^{\prime}$-bibenzene-dicarboxylate) possessing a 3D network structure. Inorg Chem Commun. 2001;4:599-601.

16. Kongshaug $\mathrm{KO}$, Fjellvåg $\mathrm{H}$. Organically pillared layered zinc hydroxides. J Solid State Chem. 2004;177:1852-7.

17. Zheng PQ, Long LS, Huang RB, Zheng LS. Crystal structure of a 3D coordination polymer: $\left[\mathrm{Cd}(\mathrm{BPDC})\left(\mathrm{H}_{2} \mathrm{O}\right)\right]_{n}(\mathrm{BPDC}=$ 4,4'-biphenyldicarboxylate). Main Group Met Chem. 2002;25: 701-2.

18. He J, Zhang Y, Yu J, Pan Q, Xu R. Two 2-D $3^{6}$ tessellated metalorganic frameworks constructed from trimetallic clusters and dicarboxylate ditopic links. Mater Res Bull. 2006;41:925-33.

19. Pan L, Finkel BS, Huang X, Li J. The first pillared threedimensional structure constructed by carboxylate ligands bridging heterometallic trilayers. Chem Commun. 2001;105-6.

20. Rzączyńska Z, Sienkiewicz-Gromiuk J, Głuchowska H. Structural and thermal properties of rare earth complexes with 2,2' biphenyldicarboxylic acid. J Therm Anal Calorim. 2010;101: 213-9.

21. Werner PE. TREOR - trial and error program for indexing of unknown powder patterns. Stockholm: University of Stockholm; 1984.

22. Łyszczek R. Comparison of thermal properties of lanthanide trimellitates prepared by different methods. J Therm Anal Calorim. 2008;93:833-8.

23. Silverstein R, Webster FX. Spectrometric identification of organic compounds. New York: Wiley; 1998.

24. Socrates G. Infrared and Raman characteristic group frequencies: tables and charts. Chichester: Wiley; 2001.

25. Łyszczek R. Hydrothermal synthesis, thermal and luminescent investigations of lanthanide(III) coordination polymers based on the 4,4'-oxybis(benzoate) ligand. J Therm Anal Calorim. 2012; 108:1101-10.

26. Teixeira KC, Moreira GF, Quirino WG, Legnani C, Silva RA, Cremona M, Brito HF, Achete CA. Rare-earth based OLEDs TGFTIR thermal stability investigation of tetrakis beta-diketonates complexes. J Therm Anal Calorim. 2011;106:587-93.

27. Czylkowska A, Markiewicz M. Synthesis, thermal behavior, and other properties of $\mathrm{Y}(\mathrm{III})$ and $\mathrm{La}(\mathrm{III})$ complexes with $4,4^{\prime}$ bipyridine and trichloro- or dibromoacetates. J Therm Anal Calorim. 2012. doi:10.1007/s10973-012-2454-8. 